\title{
MENINGKATKAN KUALITAS BLENDED LEARNING: CASE STUDY MENGGUNAKAN CoI MODEL
}

\author{
Lydiawati Kosasih Asalla \\ Jurusan Sistem Informasi, Fakultas Ilmu Komputer, Bina Nusantara University, \\ Jln K.H. Syahdan No 9, Palmerah, Jakarta Barat 11480 \\ lkosasih@binus.edu
}

\begin{abstract}
This article discusses several considerations in the education industry to achieve good quality learning by using advances in technology such as blended learning, and it uses the Community of Inquiry model as a comparison to raise quality of the blending learning program. Other aspects include on how to raise quality of a discussion as an improvement of knowledge management.

Keywords: Blended learning, Community of Inquiry

ABSTRAK

Artikel ini akan membahas beberapa pertimbangan dalam dunia pendidikan untuk mencapai pembelajaran dengan kualitas yang baik dengan memanfaatkan kemajuan teknologi seperti blended learning, dan menggunakan model Community of Inquiry sebagai studi banding untuk meningkatkan kualitas dari program blending learning. Aspek lainnya untuk bagaimana meningkatkan kualitas dari sebuah diskusi sebagai peningkatkan dari knowledge management.
\end{abstract}

Kata kunci: Blended learning, Community of Inquiry 


\section{PENDAHULUAN}

Sejalan dengan perkembangan teknologi yang semakin canggih akhir-akhir ini dan penetrasinya hampir keseluruh aspek kehidupan termasuk dalam dunia pendidikan. Pada saat ini di dunia pendidikan mulai dari sekolah sampai penguruan tinggi banyak yang telah menggunakan teknologi sebagai salah satu alat untuk mencapai keunggulan yang kompetitif. Bermula dari penggunaan teknologi sebagai alat bantu dalam kegiatan administrasi sekolah, kemudian mendukung pembuatan bahan ajar baik tahap pembuatan maupun penyampaiannya, dan sampai pada tingkat yang lebih tinggi yakni pelebaran dan pendalaman dari makna pendidikan itu sendiri, sehingga dengan pemanfaatan teknologi ini, proses belajar tidak lagi terbatas ruang dan waktu, istilah yang kita pakai untuk menyatakan hal ini adalah e-learning atau terminologi lain menyebutnya dengan blended learning.

Namun pada kenyataannya, belum semua dosen memanfaatkan teknologi sebagai sebuah alat dan sarana untuk meningkatkan proses belajar mengajar mereka. Kurang optimalnya pemanfaatan ini dilatarbelakangi oleh banyak alasan, diantaranya kurangnya kemampuan dalam menggunakan teknologi, sulitnya merubah kebiasaan cara mengajar, dan kurangnya informasi akan manfaat dari teknologi. Tapi, kita tahu sekarang bahwa banyak sekali keuntungan yang dapat kita ambil dengan memanfaatkan teknologi secara benar dan tepat dalam kegiatan proses belajar mengajar kita.

Dalam bukunya Garrison and Vaughan (2010) menyebutkan blended learning adalah sebuah desain pendekatan yang koheren dimana secara terbuka menilai dan mengintegrasikan kekuatan dari pertemuan tatap muka dan secara online untuk mencapai tujuan dari pembelajaran. Itulah kenapa kita butuh pengertian yang benar dan mendalam utnuk mengeksplorasi beberapa potensi dan strategi dari penerapan blended learning untuk mendapatkan arti sesungguhnya dari esensi pendidikan di perguruan tinggi dalam era globalisasi ini.

Dengan maksud itulah dalam artikel ini kami akan mencoba untuk mengimplementasikan sebuah model desain blended learning, dengan harapan dari adanya model ini, dosen, jurusan dan siswa akan mendapat keuntungan dari proses belajar yang terjadi. Pertama, kami akan mengelaborasi beberapa pertimbangan dalam dunia pendidikan terkait penggunakan blended learning yang berkualitas, kedua kami akan mengeksplorasi model Community of Inquiry (CoI) untuk memaksimalkan keuntungan dari penerapan program blended learning, dan terakhir fokus pada aspek bagaimana meningkatkan kualitas dari forum diskusi sebagai bagian dari knowledge management proses.

\section{HASIL DAN PEMBAHASAN}

\section{Blended Learning}

Dalam kontex dunia pendidikan, ada beberapa definsi dari blended learning. Menurut Osguthorpe \& Graham, 2003, blended learning diartikan sebagai pencampuran yang mendalam dari pengalaman tatap muka dan pembelajaran online. Kerres \& Witt (2003) menginterpretasikan blended learning sebagai campuran metode pendidikan dan format penyampaiannya. Tahun 2006, Mason and Rennie menjelaskan blended learning adalah kombinasi dari pembelajaran secara online dan tatap muka, yang selanjutnya untuk mengakomodasi kombinasi yang lebih kompleks, seperti pencampuran dari mode komunikasi yang langsung dan tidak langsung, serta diskusi yang formal dan tidak formal dan campuran metode penyampaian materinya.

Pada saat ini metode pembelajaran Blended learning sangat diminati, terutama di pendidikan 
perguruan tinggi. Menurut penelitian yang diadakan oleh Bonk, C. J.\& Graham, C. R. didapatkan 93\% perguruan tinggi menggunakan blended learning sebagai salah satu strategi di institusi mereka yang digunakan oleh dosen dan staf jurusan. 7 dari 10 perguruan tinggi mengharapkan lebih dari 40\% mata kuliah mereka diselenggarakan secara blended learning pada tahun 2013.

Tabel 1 adalah model pendekatan blended learning, dimana proses pembelajaran pada blended leanring menggunakan beberapa pendekatan seperti formal-informal, diskusi secara langsung dan tidak langsung, pembelajaran mandiri dan sebagai media untuk menunjukkan performa yang dilakukan baik oleh dosen maupun siswa.

Tabel 1. Pendekatan model Blended learning

\begin{tabular}{|l|l|}
\hline $\begin{array}{l}\text { Live face-to-face (formal) } \\
\text { Instructor-led classroom }\end{array}$ & $\begin{array}{l}\text { Live face-to-face (informal) } \\
\text { Collegial connections } \\
\text { Workshops }\end{array}$ \\
- Work teams \\
- On-the-job (OTJ) training & Role modeling \\
\hline Virtual & \\
collaboration/synchronous & Virtual collaboration/asynchronous \\
Live e-learning classes & Email \\
E-mentoring & Online bulletin boards \\
& Listservs \\
\hline Self-paced learning & Online communities \\
Web learning modules & Performance support \\
Online resource links & Help systems \\
Simulations & Print job aids \\
Scenarios & Kowledge databases \\
Video and audio CD/DVDs & - Performance/decision support tools \\
Online self-assessments & \\
Workbooks & \\
\hline
\end{tabular}

\section{Pertimbangan Dalam Meningkatkan Kualitas Blended Learning}

Beberapa pertimbangan yang perlu diperhatikan telah didefinisikan berdasarkan review dari teori mengenai dunia pendidikan dihubungan dengan proses pembelajaran pada perguruan tinggi. Alasan mendasar yang melatarbelangki adalah bagaimana tujuan dari pembelajaran di perguruan tinggi memberikan nilai tambah untuk siswa dalam proses belajarnya. Pembelajar yang dewasa umumnya dapat melakukan belajar mandiri untuk keberhasilan studinya namun masih bergantung pada keinginan hatinya, kebutuhan dan kesempatan yang ada. Bagaimanapun juga, progam pembelajaran yang ditawarkan oleh institusi termasuk Universitas harus memberikan pengalaman lebih kepada siswa dalam proses belajarnya, seperti apa yang seharusnya atau tepatnya dilakukan. Beranjak dari konsep teori pendidikan yang dasar (contempory dan classic), menyatakan bahwa proses pembelajaran bukan semata-mata sebagai transfer ilmu, namun lebih kepada memberikan nilai tambah dengan mengelola struktur bahan materi dari mata kuliah yang ada dan memfasilitasi siswa untuk dapat belajar.

\section{Hasil Pembelajaran (Outcomes Based Learning)}

Salah satu komponen terpenting dari setiap mata kuliah adalah pencapaian terhadap hasil pembelajaran. Hasil pembelajaran dapat dirancang pada tingkat jurusan maupun di setiap mata kuliah. Hasil pembelajaran ini menjadi panduan bagi dosen dan siswa, dalam hal pencapaian harapan dari ilmu dan kemampuan, proses pembelajaran dan ujian atau penilaian. Dalam bukunya di Teaching for 
Quality Learning for Higher Education, Biggs (2003) menyatakan pentingnya kesinambungan antara hasil pembelajaran yang ingin dicapai, mempersiapkan isi materi dan penilaian atau ujian dalam meningkatkan kualitas dan efektivitas dalam proses belajar mengajar.

Hasil pembelajaran yang diingin dicapai dalam mata kuliah sudah termasuk mencakup ruang lingkup topik yang akan dibahas, namun demikian sebaiknya juga termasuk pendefinisian level cognitive, afektif dan psikomotorik apa yang hendak dicapai (Bloom Taxonomy, Anderson et al, 2001).

\section{Active Learning}

Keterlibatan siswa dalam proses belajar mengajar sangat membantu dalam menciptakan atmosfer yang positif di kelas. Menurut Beard (1969), siswa tidak dapat hanya diberikan informasi dan mereka dengan cepat diharapkan untuk dapat mengerti dan menggunakannya, namun siswa harus dapat secara aktif membangun sendiri pemahaman mereka melalui tanya jawab, diskusi dan belajar mandiri serta tidak menjadi pasif. Melibatkan siswa secara aktif dapat diterapkan baik di sesi tatap muka maupun sesi online, pada prinsipnya untuk melibatkan mereka secara aktif, dosen harus memiliki pengertian yang benar terhadap karakteristik mahasiswa yang diajar (jurusan apa, IPS/IPK, gaya belajar siswa), tetap fokus pada materi yang akan dibahas, dan faktor lingkungan lainnya (aplikasi yang digunakan).

Pembelajaran yang aktif dapat juga diartikan bahwa terjadinya interaksi yang tinggi antara siswa dan materi yang sedang dibahas. Dengan demikian dosen dapat juga memberikan tugas-tugas yang menarik dan menantang berpikir kritis sehingga siswa terpicu untuk menyelesaikannya.

\section{Collaborative Learning}

Salmons (2007) mendefinisikan kolaborasi sebagai sebuah proses interaktif yang melibatkan dua atau lebih siswa yang bekerja sama untuk mencapai hasil pembelajaran dan mereka melakukannya dengan bersama-sama. Kolaborasi melibatkan baik dosen dan siswa, ataupun sesame dosen atau siswa untuk mencapai pemahaman yang lebih lanjut. Dalam hal kolaborasi yang bermanfaat atau interaksi siswa-siswa dapat tercapai dengan menggunakan berbagai cara termasuk dalam pemberian suatu tugas tertentu (Woo \& Reeves, 2007).

\section{Feedback to Students}

Salah satu komponen penting lainnya yang perlu diperhatikan adalah pemberian umpan balik oleh dosen. Beberapa aspek penting yang perlu diperhatikan dalam pemberian umpan balik adalah ketepatan waktu pemberiannya, isi dari umpan balik, dan cara kita menyampaikannya. Minimal umpan balik yang dapat diberikan oleh dosen adalah menginformasikan kepada siswa apakah tugas yang mereka telah selesaikan dan kumpulkan masih membutuhkan perbaikan atau sudah sesuai dengan yang diinstruksikan. Mengenai ketepatan waktu juga perlu diperhatikan oleh dosen, jika dosen terlalu lama dalam memberikan umpan balik, maka hal ini dapat menurunkan motivasi siswa, sehingga merupakan hal yang bijaksana jika respon tersebut dapat diberikan secepatnya oleh dosen, jika memungkinkan maksimal sebelum pertemuan selanjutnya berjalan. Terkait isi dari umpan balik haruslah jelas dan terstruktur, tidak ambigu, sehingga siswa mendapat informasi dan penjelasan yang benar dan tepat, walaupun tidak perlu selalu harus tatap muka, misalnya umpan balik ketika sesi online. Cara penyampaiannya, kita dapat menggunakan dengan pendekatan "sandwich feedback", dimana kita memberikan informasi secara keseluruhan yang merupakan sisi positif dari hasil tugas tersebut, diikuti dengan pemberian saran atau komentar, dan terakhir ditutup dengan afirmasi atau motivasi yang positif kembali.

Untuk formative assessment, pemberian umpan balik juga sangat penting dilakukan, dosen 
dapat mengidentifikasi beberapa pertanyaan yang diajukan siswa dan dapat bertanya kembali untuk mendapat masukkan dan jawaban dari mereka, terkait proses pembelajaran, materi pembelajaran, dan penyampaian yang dilakukan dosen serta situasi kelas. Hal ini dapat kita lakukan diawal perkuliahan, misalnya di sesi 2 sampai 4, sehingga dosen mendapat pemahaman yang baik mengenai situasi yang sedang berlangsung dan apa saja yang perlu dilakukan untuk memperbaikinya.

Bridge and Appleyard (200), mengadakan penelitian pendapat siswa mengenai umpan balik khususnya di sesi online. 93\% siswa menyatakan bahwa umpan balik di sesi online lebih cepat mereka terima daripada di sesi tatap muka, secara keseluruhan 56\% lebih menyukai umpan bali secara online, walaupun $6 \%$ diantara lebih menyukai umpan balik yang melekat pada tugas yang mereka kumpulkan.

\section{Learning Styles}

Siswa menerima dan memproses informasi dengan cara yang berbeda-beda, yang kita sebut dengan gaya belajar siswa. Ada beberapa teori yang membahas mengenai gaya belajar ini, diantaranya ada teori umum yang kita kenal yakni Visual, Auditory dan Kinesthetic, dan ada pula Pragmatist, Auditory, Reflector dan Theorist yang diperkenalkan oleh Honey \& Mumford.

Semua teori gaya belajar ini, penting untuk dipahami oleh dosen, dan disesuaikan dengan rancangan metode instruktional nya. Dan menyediakan media untuk penyampaian materinya dengan baik dan benar, seperti materi presentasi, video, simulasi, multimedia, studi kasus, dan disesuaikan dengan karakteristik gaya belajar siswa dalam kelas tersebut.

\section{Community Of Inquiry}

Menurut Dewey, dalam pendidikan proses bertanya adalah suatu proses menginvestigasi suatu masalah dan isu yang ditimbulkan, bukan hanya sekedar mengingat solusi yang didapatkan. Proses bertanya dalam sebuah komunitas pendidikan berfokus pada tujuan dan hasil pembelajaran. Proses ini merupakan sebuah proses yang sistematis untuk mendefinisikan pertanyaan-pertanyaan yang relevan, melakukan penyelidikan untuk informasi yang berkaitan, mencari alternatif solusi dan penerapan dari solusi tersebut. Dengan menggunakan forum diskusi kita mengkaitkan kurikulum melalui sebuah refleksi dari diskusi tanya jawab yang terjadi. Sebuah Community of Inquiry bergantung pada kelangenggan suatu komunikasi dan kolaborasi dimana semua pesertanya, baik dosen dan siswa mensharingkan pengalaman dan pandangan mereka. Mereka diharapkan untuk dapat aktif dan fokus pada topik dan tugas yang sedang dibahas terkait mata kuliahnya.

Proses pembelajaran mendefinisikan proses bertanya merupakan sesuatu yang melebihi dari sekedar cara akses atau bahkan asimilasi informasi. Proses bertanya menggabungkan proses belajar dan hasil pembelajaran menjadi satu kesatuan yang terus dapat berulang. Proses bertanya menghubungkan refleksi pribadi dan materi dengan mendorong siswa untuk mengeksplore secara kolaborasi bersama-sama dalam grup dan memberikan pertanyaan yang mendalam dan masuk akal dari materi pembahasan yang ada, sehingga proses bertanya yang benar adalah terjadinya refleksi dari hasil diskusi tanya jawab dan mendapat pembelajaran dari pengalaman pada proses tersebut. Proses bertanya harus memiliki tujuan, tapi juga flesibel, untuk mengekplorasi ketertarikan yang belum terlihat dari proses tersebut. Hubungan personal punya peranan penting dalam sebuah Community of Inquiry, tapi itu bukan merupakan tujuan akhirnya. Community of Inquiry yang sukses bergantung pada tujuan dan hubungan yang saling menghormati yang mendorong baik dosen dan siswa bebas untuk mengemukakan pendapat sehingga komunikasi terbuka terjadi.

Kerangka Community of Inquiry (CoI) menyediakan urutan dan panduan untuk melakukan eksplorasi pada desain blended learning dengan menghadirkan proses dan hasil pembelajaran yang terbentuk secara koheren dan akurat. 
Sebuah komunitas pembelajaran adalah pembentukan secara formal grup yang terdiri dari beberapa siswa yang memiliki koneksi, yakni tujuan akademik yang sama (misalnya jurusan dan semester yang sama), dan bekerja sama untuk mencapai tujuan dan hasil pembelajaran. Tujuan dari grup atau komunitas tersebut menentukan bagaimana grup tersebut belajar dan berkembang. Dari sudut pandang pendidikan, ketertarikan terhadap mata kuliah tersebut harus menjadi fokus yang utama. Komunitas yang terbentuk harus dikembangkan untuk mendukung proses pembelajaran yang sistematik mulai dari diskusi penentuan masalah yang akan dibahas sampai kepada cara pemecahannya.

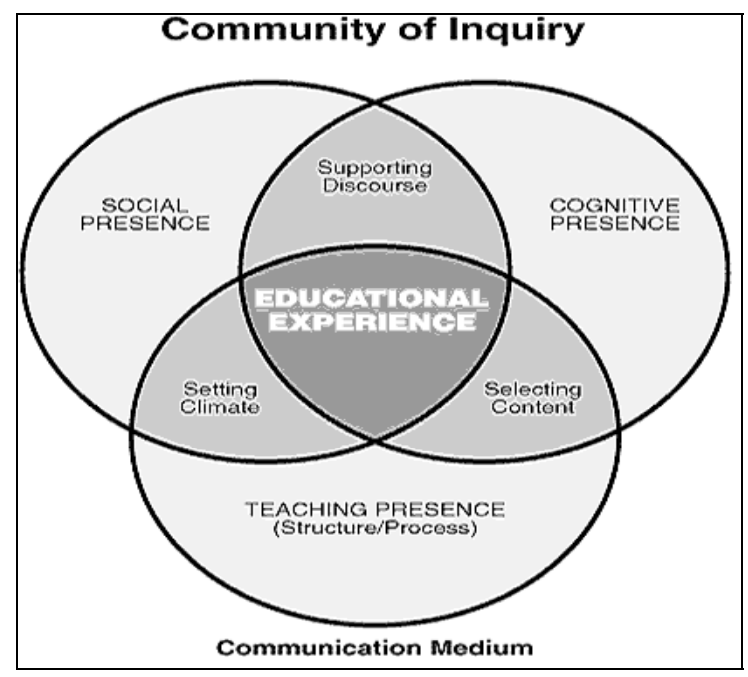

Gambar 1. Kerangka Community of Inquiry

Seperti sudah disebutkan diatas, kerangka CoI (Gambar 1) menyediakan urutan secara konseptual dan hal tersebut telah terbukti menunjukkan validitas empiris yang kuat (Arbaugh, 2007; Garrison, Cleveland-Innes \& Fund, 2004). Kerangka CoI adalah sebuah model berulang untuk setiap elemen intinya dan saling mendukung satu sama lain, seperti yang dilihat pada Gambar 1. Tiga elemen dari kerangka CoI adalah adanya hubungan sosial (social presence), adanya tingkat pemahaman yang dicapai (cognitive presence), dan metode mengajar yang tepat (teaching presence). Masing-masing elemen mencerminkan kategori dan indikator yang biasa digunakan pada proses belajar mengajar. Merupakan hal yang sangat penting untuk mengerti ketiga elemen tersebut saling bergantung, bahwa satu elemen dapat mempengaruhi elemen yang lainnya. Sebagai contoh, metode pengajaran akan sangat berdampak dan mempengaruhi pencapai tingkat pemahaman materi yang dibahas, dan hubungan sosial yang terjalin dapat komunikasi atau kelas tersebut juga dapat mempengaruhi siswa untuk mencapai tujuan pembelajaran. Dibagian selanjutnya kita akan membahas satu per satu dari setiap elemen yang ada serta hal-hal penting yang dapat diperhatikan dan tips melakukannya.

\section{Hubungan social (Social Presence)}

Sebagai makhluk sosial, kebutuhan mendasar manusia adalah untuk dapat berinteraksi dan menjalin komunikasi dengan sesamanya. Untuk membuat suatu hubungan yang baik dan berkelanjutan membutuhkan sebuah komunikasi yang terbuka dimana ada rasa saling percaya satu dengan yang lainnya. Dalam hal social presence pada model blended learning, memiliki pemahaman dasar yang sama, jika seorang dosen ingin memelihara relasi dan komunikasi yang baik dengan siswa, harus tercipta dulu situasi yang kondusif, adanya respon yang positif, koneksi personal dan komunikasi yang afektif, seperti yang terlihat pada Tabel 2. Kategori ini harus ada, dipertahankan dan harus dapat dikembangkan dalam sebuah CoI. 
Tabel 2 Community of Inquiry Framework

\begin{tabular}{cll}
\hline Elements & Categories & Indicators (examples only) \\
\hline Social & Open communication & Enabling risk-free expression \\
presence & Group cohesion & Encouraging collaboration \\
& Affective/personal & Expressing cmotions, camaraderie \\
Cognitive & Triggering cvent & Having sense of puzzlement \\
presence & Exploration & Exchanging information \\
& Integration & Connecting ideas \\
& Resolution & Applying new ideas \\
Teaching & Design \& otganization & Setting curriculum and methods \\
presence & Facilitation of discourse & Sharing personal meaning \\
& Direct instruction & Focusing discussion \\
\hline
\end{tabular}

Dosen memiliki tanggung jawab dapat menciptakan suasana yang kondusif dan mampu membina relasi baik dirinya dengan siswa, maupun hubungan yang terjalin antar siswa. Walaupun pada kenyataannya hal ini membutuhkan waktu yang cukup untuk siswa dapat merasa nyaman dan percaya pada komunitas atau kelas tersebut, namun demikian hal ini bisa terjadi dengan memperhatikan juga keterikatan emosi dan persahabatan yang ada akan menciptakan hubungan sosial dan komunitas edukasi yang baik.

Dengan adanya relasi seperti ini juga menciptakan rasa memiliki satu sama lain dalam kelas tersebut, saling mendukung dalam mengekpresikan kebebasan berpendapat, dan memelihara kesatuan, karena CoI khususnya elemen social presence ini tidak sama dengan diskusi online biasa.

Prinsip yang dapat kita terapkan adalah sebagai dosen, yang pertama kita harus menciptakan iklim yang kondusif dikelas, dengan demikian diharapkan siswa tidak takut untuk berpendapat, mereka dapat mengemukakan pendapat mereka dengan bebas dan terbuka, sebagai tanda proses pembelaran mulai terjadi; dan kedua kita dapat memberikan respon yang positif dari diskusi yang terjadi, sehingga rasa percaya dan nyaman dapat mulai dirasakan oleh siswa, dengan demikian mereka akan terus berani mengemukakan pendapat mereka; dan yang ketiga untuk keberlanjutan sampai pada akhir semester, kita dapat membuat komitmen kelas secara bersama-sama, tentu saja dengan dipimpin oleh dosen, yang mencakup apa, kenapa dan bagaimana kita akan menjalankan perkuliahan ini baik secara tatap muka maupun sesi online.

Pertemuan pertama adalah pertemuan yang sangat penting bagi dosen untuk menciptakan situasi yang kondusif, akrab dan rasa saling percaya antara dosen dan siswa maupun siswa dengan siswa. Hal ini dilakukan bukan hanya di pertemuan tatap muka melainkan juga di sesi online melalui forum diskusi (Gambar 2). Kalimat sapaan dan ajakan untuk berkontribusi aktif dalam kelas dapat kita utarakan disini, dan dari pengalaman dan pengamatan bahwa hal ini sangat terbukti bermanfaat, siswa jadi merasa bagian dari grup dan saling membina perkenalan diantara grup, dibawah ini adalah contoh untuk diskusi di pertemuan awal. 


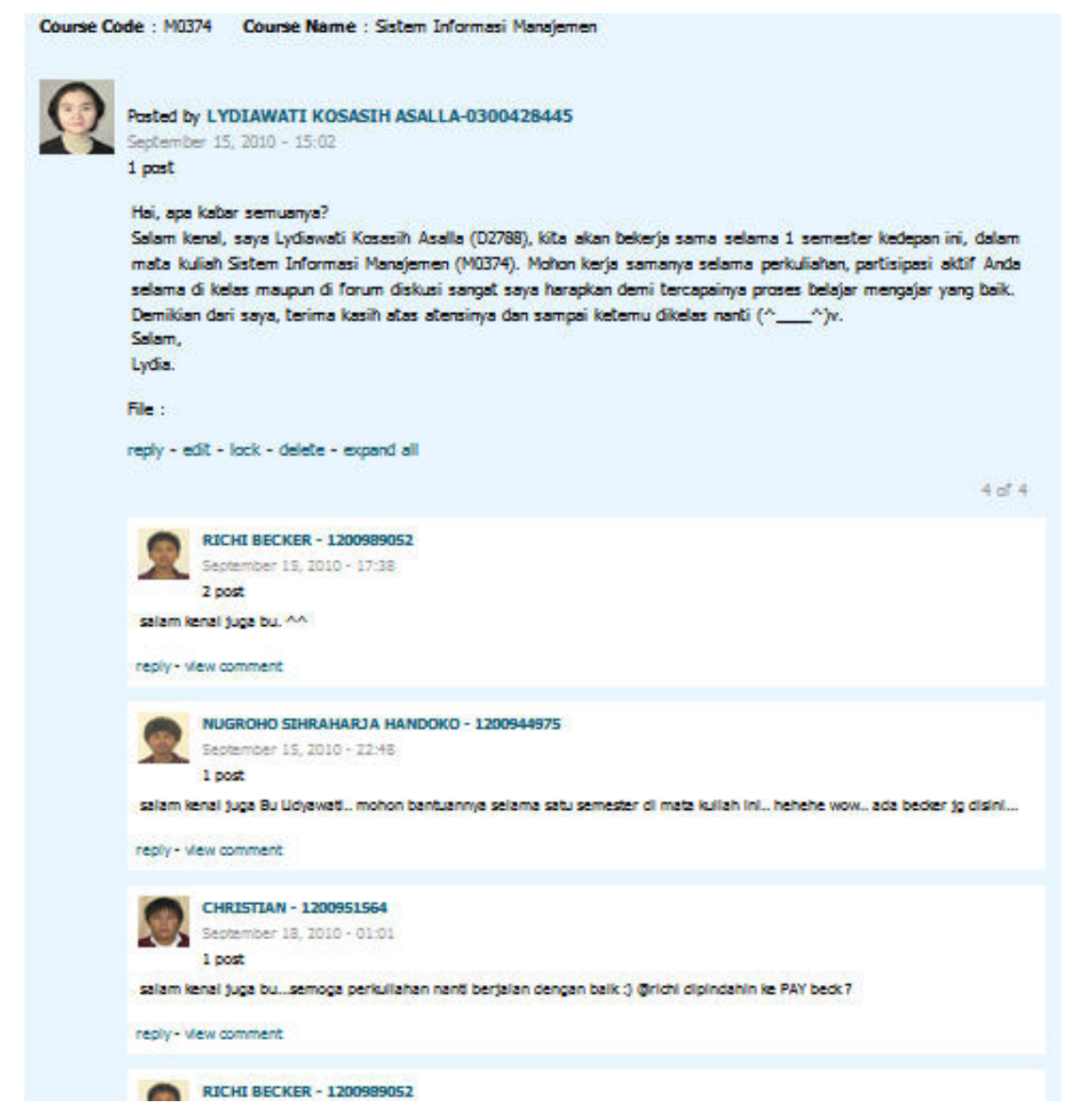

Gambar 2. Contoh Forum Diskusi - Social Presence

\section{Pencapaian Tingkat Pemahaman (Cognitive Presence)}

Sebagai bagian dari proses belajar mengajar, apapun media yang digunakan itu haruslah mendukung terjadinya transformasi pengetahuan (knowledge), kemampuan (skill) dan sikap (attitude). Dalam memberi perhatian yang besar pada tranformasi peningkatkan pemahaman, proses bertanya (inquiry) sangat berkaitan erat, mulai dari dipicu dengan pertanyaan yang kritis dan menyelidik hingga menuju simpulan untuk beberapa alternatif solusi. Pada umumnya setiap mata kuliah sudah ada tujuan dan hasil pembelajaran yang akan dicapai baik secara umum maupun setiap sesinya, dan proses bertanya atau diskusi harus tetap pada ranah tersebut sehingga tidak melebar dan pencapaian hasilnya dapat diukur.

Menurut Garrison and Vaughan (2010) seperti yang terlihat pada gambar 3, menjelaskan penerapan proses bertanya atau diskusi memiliki 2 dimensi dan 4 tahapan. Garis vertikal menunjukkan proses mempertimbangkan untuk pengambilan keputusan. Hal ini menunjukkan proses berulang yang alami dari proses diskusi dalam menghadirkan baik aktivitas pemahaman bertingkat dan pemikiran yang didapat dari hasil kolaborasi. Garis horizontal menunjukkan gambaran dari persepsi yang diterima akibat dari diskusi yang terjadi. Hal ini terjadi karena adanya proses pemahaman yang bertingkat dari sharing pengalaman diskusi yang terjadi.

Cognitive presence adalah sebuah proses yang berulang, dimana siswa melakukan pertukaran informasi, menghubungan ide dan gagasan satu sama lain, menciptakan konsep yang baru, dan mencoba kebenaran dari alternatif solusi yang disimpulkan, dan terkadang mereka diharuskan lebih memfokuskan diri untuk melakukan eksplorasi lebih lanjut, dari ide, gagasan atau solusi yang dipilih. 
Pada program blended learning, siswa memiliki kesempatan untuk meningkatkan proses belajar mereka dengan mengintegrasikan komunikasi verbal dan tertulis, dimana kita ketahui perpaduan dari kedua proses ini memberikan hasil yang positif bagi siswa dalam mereka mendapatkan ilmu tersebut.

Prinsip yang dapat kita lakukan untuk tahap cognitive presence sebagai dosen adalah pertama kita harus merencanakan saat-saat siswa dapat melakukan refleksi yang kritis dari materi bahasan yang ada, kedua memanfaatkan forum diskusi sebagai perpanjangan diskusi yang terjadi di kelas, dan terakhir memberikan tugas-tugas yang mendukung proses bertanya atau berdiskusi itu dapat terjadi. Sebagai bagian dari proses pembelajaran, dosen diharuskan memberikan umpan balik dan rangkuman dari setiap proses diskusi yang terjadi. Dosen juga diharapkan memberikan pertanyaan atau pernyataan awal, yang menyebabkan siswa mulai dapat berpikir kritis dan dilanjutkan dengan proses diskusi diantara siswa. Proses diskusi ini dapat dibuat per-individu ataupun grup, untuk kasus kelas besar akan lebih sering menggunakan diskusi grup, dimana aturan untuk hal ini harus dipahami dan diketahui siswa dari awal, misalnya ada grup yang bertugas memberikan konsep-konsep terkait dan ada grup yang memberikan fakta-fakta yang ada, dengan demikian diskusi bisa dilanjutkan.

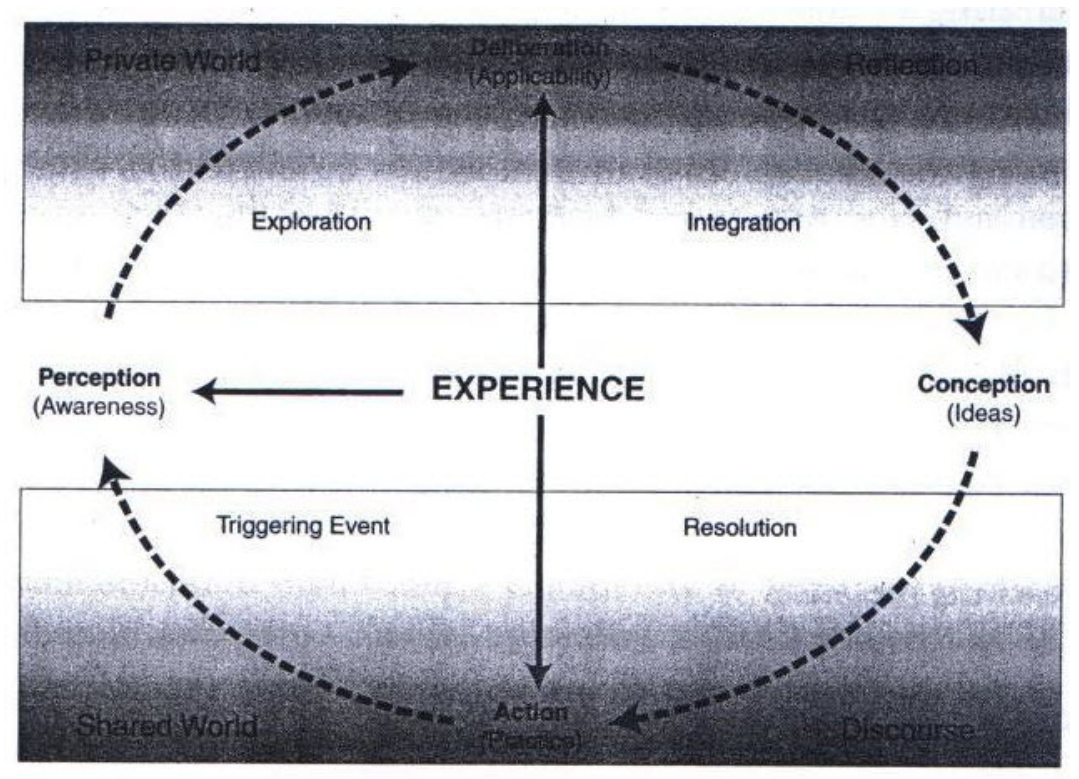

Gambar 3 Practical Inquiry Model

Sama hal-nya dengan elemen social presence, bahwa di pertemuan pertama merupakan momen yang sangat krusial dan penting, untuk menyampaikan tujuan umum dan khusus yang akan dicapai dalam mata kuliah tersebut. Memberikan gambaran keseluruhan dari pokok bahasan dan metode penyampaiannya, seperti yang akan kita bahas pada elemen selanjutnya, akan sangat membantu siswa untuk melihat gambar secara utuh apa yang akan mereka lalui dan lakukan, serta sejauh apa kontribusi aktif mereka diharapkan. Dengan demikian siswa akan merasa lebih dilibatkan dan mau dengan rela melibatkan diri untuk kesuksesan pembelajaran. Tabel 3 di bawah ini adalah contoh sederhana yang dapat di share ke siswa pada pertemuan awal untuk mendapat kesepakatan dan pemahaman yang sama akan tujuan yang akan dicapai. 
Tabel 3. Agenda Keseluruhan

\begin{tabular}{|c|c|c|c|c|}
\hline \multicolumn{5}{|l|}{ Agenda Perkuliahan Overall } \\
\hline \multicolumn{2}{|l|}{ M000_Sistem Informasi Manajemen } & \multicolumn{3}{|c|}{ D0000 - Lydiawati Kosasih Asalla } \\
\hline \multicolumn{5}{|c|}{$\begin{array}{l}\text { Matakuliah ini mempelajari tentang perubahan-perubahan dalam bisnis yang dapat mempengaruhi } \\
\text { perusahaan untuk berubah dan juga perkembangan teknologi berpengaruh dalam membantu } \\
\text { perusahaan dalam mengembangkan diri dan tipe-tipe sistem informasi apa saja yang dapat } \\
\text { membantu, dan perusahaan dalam berkembang }\end{array}$} \\
\hline Pokok Bahasan & Pertemuan & Mode & Chapter & Lect IDisc \\
\hline Ekonomi Lama dan Ekonomi Baru [1] & \begin{tabular}{|c|} 
\\
\end{tabular} & $\mathrm{F} 2 \mathrm{~F}$ & 1 & \multirow{2}{*}{ Lect } \\
\hline Ekonomi Lama dan Ekonomi Baru [2] & 2 & F2F & 1 & \\
\hline Konsep Sistem (1) & 3 & $\mathrm{~F} 2 \mathrm{~F}$ & 2 & \multirow{2}{*}{ Lect } \\
\hline Konsep Sistem [2] & 4 & F2F & 2 & \\
\hline Decision Support System [1] & 5 & OFC & 2 & \multirow{2}{*}{ GSLC } \\
\hline Decision Support System [2] & 6 & $\mathrm{OFC}$ & 2 & \\
\hline Konsep Sistem dan Manajemen (1) & 7 & F2F & 2 & \multirow{2}{*}{ Disc 1} \\
\hline Konsep Sistem dan Manajemen [2] & 8 & F2F & 2 & \\
\hline Database dan Database Management System (1) & 9 & F2F & 3 & \multirow{2}{*}{ Disc 2} \\
\hline Database dan Database Management System (2) & 10 & F2F & 3 & \\
\hline Komunikasi Data (1) & 11 & F2F & 4 & \multirow{2}{*}{ Disc 3} \\
\hline Komunikasi Data [2] & 12 & F2F & 4 & \\
\hline Wireless [1] & 13 & F2F & 6 & \multirow{2}{*}{ Lect } \\
\hline Wireless [2] & 14 & F2F & 6 & \\
\hline \multicolumn{5}{|c|}{ Quiz 1} \\
\hline \multicolumn{5}{|c|}{ Upan Tengas Semester } \\
\hline E-Commerce dan E-Business [1] & 15 & $\mathrm{~F} 2 \mathrm{~F}$ & 5 & \multirow{2}{*}{ Disc 4} \\
\hline E-Commerce dan E-Business [2] & 16 & F2F & 5 & \\
\hline E-Commerce \& Case (1) & 17 & $\mathrm{DFC}$ & 5 & \multirow{2}{*}{ GSLC } \\
\hline E-Commerce \& Case [2] & 18 & $\mathrm{OFC}$ & 5 & \\
\hline Functional Transaction Processing [1] & 19 & $\mathrm{~F} 2 \mathrm{~F}$ & 7 & \multirow{2}{*}{ Disc 5} \\
\hline Functional Transaction Processing (2) & 20 & $\mathrm{~F} 2 \mathrm{~F}$ & 7 & \\
\hline ERP dan Supply Chain [1] & 21 & $\mathrm{~F} 2 \mathrm{~F}$ & 8 & \multirow{2}{*}{ Disc 6} \\
\hline ERP dan Supply Chain (2) & 22 & $\mathrm{~F} 2 \mathrm{~F}$ & 8 & \\
\hline CRM(1) & 23 & $\mathrm{OFC}$ & 8 & \multirow{2}{*}{ GSLC } \\
\hline CRM(2) & 24 & $\mathrm{OFC}$ & 8 & \\
\hline Sistem Pengetahuan (1) & 25 & F2F & 10 & \multirow{2}{*}{ Lect } \\
\hline Sistem Pengetahuan (2) & 26 & F2F & 10 & \\
\hline \multicolumn{5}{|c|}{ Quiz 2} \\
\hline \multicolumn{5}{|c|}{ L/pan skajir Semester } \\
\hline
\end{tabular}

\section{Metode Penyampaian Materi (Teaching Presence)}

Seperti kita ketahui bahwa baik pada saat sesi tatap muka maupun sesi online, dosen tetap diharuskan mengimplementasikan metode pembelajaran yang baik dan benar, jadi teaching presence merupakan elemen yang penting untuk membuat kedua elemen sebelumnya menjadi suatu yang produktif. Aktivitas pembelajaran yang semula hanya dirancang untuk pembelajaran pada saat sesi tatap muka sekarang juga sudah mulai direncanakan untuk sesi online.

Pada elemen ini, dosen diharapkan dan dminta untuk merancang, memfasilitasi dan mengarahkan agar proses pembelajaran itu dapat terjadi. Dosen berkewajiban untuk mempersiapkan materi dari pokok bahasan yang ada, juga menyediakan cara pendekatan dan metode penyampaian serta aktivitasnya, termasuk menyediakan arahan, panduan dan fokus topik diskusi dan tugas-tugas terkait. Menciptakan materi baik untuk sesi online dan tatap muka yang berkualitas baik merupakan sebuah tantangan bagi dosen. Terlebih lagi hal tersebut membutuhkan sumber-sumber lainnya sebagai materi tambahan yang dapat digunakan sebagai bahan diskusi baik pada saat sesi tatap muka maupun online. 
Aspek penting lainnya pada elemen teaching presence adalah jiwa kepemimpinan dari seorang dosen, karena dengan demikian dosen dapat memimpin siswa kepada tujuan, yakni siswa dapat meningkatkan level pemahamannya terhadap materi dan belajar dari proses pembelajaran itu sendiri (metacognitive). Mengadopsi dari gagasan Garrison and Vaughan (2010), metacognitive adalah proses dari pembentukan dari suatu pemahaman, dimana siswa dapat menilai apa yang harusnya dilakukan, dan mengelola diri untuk belajar mandiri dengan demikian dia dapat menyelesaikan tugas-tugas yang ada.

Prinsip yang dapat kita terapkan adalah dosen harus memastikan bahwa penilaian dari tugas maupun ujian harus sesuai dengan hasil pembelajaran yang ingin dicapai. Setiap aktivitas, diskusi dan ujian yang berlangsung harus dipantau dan diarahkan untuk pencapaian hasil pembelajaran.

Untuk itu diperlukan juga aturan yang jelas dan hal ini dari awal perlu diketahui oleh siswa, sehingga siswa dapat mengerti mereka bisa mendapatkan nilai pada sesi apa dan dengan cara apa. Ketentuan dan aturan ini diperlukan baik di sesi tatap muka maupun sesi online. Tabel 4 dan Tabel 5 di bawah ini adalah contoh prosedur yang dapat dilakukan ketika sesi tatap muka maupun sesi online sehingga setiap sesi dapat dilakukan dengan baik dan mencapai tujuannya.

Tabel 4. Prosedur Sesi Tatap Muka

\begin{tabular}{|l|l|}
\hline $\begin{array}{l}\text { Prosedur Discussion on Class } \\
\text { The Adjusment }\end{array}$ \\
\cline { 2 - 2 } & Kelengkapan Materi Presentasi \\
\cline { 2 - 2 } Presenter : & Kehadiran Tim Presentasi \\
\cline { 2 - 2 } & Kekompakkan Tim Presentasi \\
\cline { 2 - 2 } & Differentiate yang disediakan \\
\hline Challenger : & Bobot Pertanyaan Tim Challenger \\
\hline & Kekompakkan Tim Challenger \\
\hline Others: & $\begin{array}{l}\text { Pertanyaan/tanggapan yang diberikan } \\
\text { kepada tim Presenter (sebagai nilai pribadi) }\end{array}$ \\
\hline
\end{tabular}

Tabel 5. Prosedur Sesi Online

\section{Prosedur Discussion OFC}

\begin{tabular}{|l|l|l|} 
& $\begin{array}{l}\text { Anggota tim wajib melemparkan suatu topik } \\
\text { (sesuai dengan materi pada minggu tersebut) } \\
\text { Quntuk didiskusikan bersama, dan memberi } \\
\text { tanggapan atas jawaban yang diberikan } \\
\text { teman2nya }\end{array}$ & $\begin{array}{l}\text { Format: Nama Kelompok_Nama Pribadi, } \\
\text { Contoh : Excellent_Lydia }\end{array}$ \\
\hline Answer: & $\begin{array}{l}\text { Anggota tim wajib menjawab } \\
\text { tantangan/diskusi yang diberikan }\end{array}$ & $\begin{array}{l}\text { Format: Nama Kelompok_Nama Pribadi, } \\
\text { Contoh : Excellent_Lydia }\end{array}$ \\
\hline & $\begin{array}{l}\text { Boleh memberikan jawaban/tanggapan dan } \\
\text { dianggap sebagai nilai pribadi }\end{array}$ & Format: Nama Pribadi saja \\
\hline
\end{tabular}




\section{SIMPULAN}

Model terkini dari blended learning sudah mengikutkan komponen penting yang bertujuan untuk membuat proses pembelajaran yang lebih efektif dan produktif, dimana bahan materi sudah siap pakai baik untuk sesi tatap muka maupun sesi online, termasuk penyedian forum untuk keberlanjutan diskusi yang tidak dibatasi hanya di dalam kelas, tapi juga di luar kelas dan sebagai alat untuk bertukar pikiran. Namun bagaimanapun juga, pergeseran dari kelas tradisional, dimana pembelajaran hanya terjadi dikelas menjadi kelas dengan dukungan teknologi, yakni blended learning, belum mencapai titik yang maksimal, hal ini terjadi karena masih banyak dosen maupun staff jurusan masih mendapati kesulitan untuk mengubah proses pembelajaran mereka.

Seperti kita ketahui, bahwa faktanya masih banyak dosen dan siswa yang tetap berpikir bahwa sesi tatap mukalah yang memiliki peran paling penting, dan menghiraukan serta tidak memanfaatkan maksimal sesi online. Namun pada kenyataannya, melalui sesi online proses pembelajaran dapat lebih dalam di elaborasi, dan tidak dibatasi oleh ruang kelas dan waktu kuliah. Dengan adanya model blended learning ini, diharapkan dosen dan siswa dapat melihat dan memanfaatkan maksimal kekuatan dan sisi positif dari sesi tatap muka maupun sesi online.

Disamping itu model pembelajaran blended learning juga memiliki keuntungan lainnya, baik untuk siswa, dosen dan staff jurusan dengan meningkatkan efesiensi dan efektifitas, dengan blended learning penggunaan ruang kelas dapat lebih dimaksimalkan, mengurangi lalu lintas kampus, mengurangi biaya operasional dari pemberian materi karena telah didukung oleh teknologi dan pencapaian hasil pembelajaran yang lebih mendalam karena tidak terbatas pada sesi tatap muka saja. Fleksibilitas memiliki nilai tersendiri dalam model ini dan juga personalisasi, sehingga siswa dapat maksimal di waktu-waktu yang dapat mereka sesuaikan sendiri untuk kenyamanannya.

\section{DAFTAR PUSTAKA}

Aprina. (2008), Penerapan E-Learning Vs Blended Learning di dalam Pembelajaran Jarak Jauh. Mini Paper Sistem Informasi Manajemen.

Dziuban, C. D. (2004) Blended Learning. EDUCAUSE Center for Applied Research. Vol 2004, Issue 7.

Garrison, D. R., \& Vaughan, N. D. (2008). Blended learning in Higher Education. ISBN 978-0-78798770-1. A Wiley Imprint, San Fransisco 